ECONOMICS (b) Clacialagy

\author{
Rayenda Khresna \\ Brahmana, \\ Universiti Malaysia Sarawak, \\ Sarawak, Malaysia, \\ E-mail:raye_brahm@yahoo.com
}

\author{
Simon Kopong, \\ Centre for Policy Research and \\ International Studies, \\ Universiti Sains Malaysia, \\ Penang, Malaysia, \\ E-mail: sapporata@gmail.com
}

Ritzky Karina Brahmana,

Universitas Kristen Petra Surabaya, Siwalankerto, Jawa Timur,

Indonesia,

E-mail:karina@petra.ac.id

Received: May, 2015

1st Revision: October, 2015

Accepted: November, 2015

DOI: $10.14254 / 2071-$

789X.2015/8-4/16

JEL Classification: N45
Brahmana, R. K., Kopong, S., Brahmana, R. K. (2015), Optimism and

Consumption: Psychological Costs of Malaysia-Sulu Dispute, Economics and

Sociology, Vol. 8, No 4, pp. 225-240. DOI: 10.14254/2071-789X.2015/8-4/16

\section{OPTIMISM AND CONSUMPTION: PSYCHOLOGICAL COSTS OF MALAYSIA-SULU DISPUTE}

\begin{abstract}
This research aims to examine the moderating effect of optimism on the relationship between psychological cost and consumption level during disputes. Psychometric-based questionnaire was developed and distributed in March 2013 to find Sabahan had severe symptoms of stress. This stress level induced the consumption level and also leisure cost in attempts to overcome the dispute. Interestingly, those Sabahans who were more inclined to optimism-might rethink their consumption/spending decision making. In other words, there is a moderating effect of optimism on the relationship between stress level and consumption during disputes.
\end{abstract}

Keywords: Stress Level; Optimism; Consumption; Dispute; Sabah Malaysia.

\title{
Introduction
}

In late 2012 there was a Sulu dispute at Sabah Malaysia, and it received massive international attention. "Time" magazine reported 26 people died because of the dispute ${ }^{1}$ within two months period. The dispute caused mental health problems to locals who lived in the conflict areas ${ }^{2}$.

The dispute of Sulu, Malaysia was started by the argument about the ancient territory of Sulu Sultanate, the heirs of the Sultanate claim north east of Borneo, which is part of Sabah Malaysia, as Sulu archipelago. These Sulu tribes, such as Bajau, Sulukh, Tausug, have lived in southern part of the Philippines and the Northern part of Borneo centuries ago as traders. After the occupation by Japan in 1961, the Sultanate of Sulu signed the "Pajak" treaty with Persekutuan Tanah Melayu (Federal States of Malay). This "Pajak" treaty is the document

\footnotetext{
${ }^{1}$ See http://world.time.com/2013/03/04/malaysia-at-least-26-dead-in-ongoing-sabah-siege/

${ }^{2} \mathrm{http}$ ://dinmerican.wordpress.com/2013/03/05/lahad-datu-incursion-our-leaders-have-failed-not-just-sabahans/
} 
behind the dispute, the Philippines claims that the term "pajak" means "lease" while the Malaysias claims that it means "cession". "Lease" means a contract by which a rightful possessor of real property conveys the right to use (or occupy) the property, usually rent, while"cession" means the relinquishment or transfer of land from one state to another.

On October 7, 2012, the Philippines President, Benigno Aquino, announced a framework peace agreement to resolve this problem, however, by involving only the Moro Islamic Liberation Front, but not the heirs of Sultanate of Sulu. As a result, the rest of Sulu heirs felt left out in the agreement. 11 November 2012, Sultan Jamalul Kiram III, who claims to be the rightful heir to the throne of Sulu declared that civil and military contingents should assert their rights for the territory of North Borneo (Sabah Malaysia), and appointed his brother and Easy King ("heir" or "crown prince"), Agbimuddin Kiram, to lead a group infiltrating Sabah Malaysia ${ }^{3}$.

In February, 2013, this group sent their 200-soldier royal army to Malaysia thus beginning the dispute. In 2 months, 26 people already died in the course of the dispute ${ }^{4,5}$.

Because of the whole situation basing on our field observation in March 2013, people have lived in fear and anxiety, especially after the second wave of Sulu intrusion in July 2013.

This situation has brought many questions to the limelight of social sciences research, considering that previously the Malaysians have lived peacefully in Sabah, and did not have any dispute record in this northern Borneo area. These questions include inter alia: Did the Malaysians in that region have stressful feelings during the dispute? Do they still have optimism in life? Do they engage more in leisure activities to overcome the stress? Does optimism help them reduce anxiety and consumption? These are the questions this research aims to tackle.

Besides that, this paper attempts to answer empirically challenging questions "Does stress bring in extra consumption and extra leisure spending?", and also "Is there any moderating effect on the relationship between stress level and consumption?"

The rest of the paper is organized as follows: section 1 addresses the background of the dispute. Section 2 delivers data and methodology. The results of estimation are in section 3, and Section 4 elaborates the findings and literature as one comprehensive discussion. Lastly concludes.

\section{Literature Review}

Indeed, war or dispute or conflict always has its own price. It gives a loss to a nation, both to wealth and mental health. Many research findings such Ross (2007), Goldsmith (2008), and Scheve and Stasave (2012) have investigated the relationship between war and national wealth. Others such Hirsch and Mehay (2003), Tanielian and Jaycox (2008), and Cesur et al. (2012) consider psychological cost as outcome of dispute. For instance, Cesur, et al. (2012) investigated the psychological cost of war of Americans who went to Iraq. They found that soldiers who went for war against Iraq suffered from post-traumatic stress disorder (PTSD).

So far, research has been also extensively conducted in investigating the association between cost of war and macroeconomics output. Scheve and Stasavage (2012) addressesed inheritance tax system and income equality might be the cost of the war, which is in line with

\footnotetext{
${ }^{3}$ See http://thestar.com.my/news/story.asp?file=/2013/2/19/nation/12729524.

${ }^{4}$ See http://world.time.com/2013/03/04/malaysia-at-least-26-dead-in-ongoing-sabah-siege/

${ }^{5}$ Authors went to Sabah in March 2013 to observe and conduct data collection. Lahad Data and Samporna are in a high tense situation, where many Malaysia's Army did a road block or built a small post in streets; a uncommon situation for Malaysian. Authors did interview several citizens about their condition in this dispute. Many of them experienced stress and anxiety.
} 
Bank, Stark, and Thorndike (2008) who found how participation in World War I led to political pressures for steeply progressive taxes in the UK and US. Abadie and Gardeazabal (2003) investigated the economic effects of conflict in Basque Country Spain. They found GDP per capita of Basque Country declined about 10 percent after the outbreak of terrorism in the late 1960. However, during a peace period, GDP and relative performance were increasing. Study of dispute and conflict in Sri Lanka by Arunatilake, Jayasuriya, and Kelegama (2001) gave the similar conclusion. Their estimation suggested that the cost of conflict since 1983 until 1996 might be equal to twice of Sri Lanka GDP in 1996, and this cost pushed poverty figure to increase. Note that all of those studies conducted by secondary data of macroeconomic output. None of it investigated the role of war or conflict on personal expense in regards of overcoming stress or anxiety.

This paper is different from other papers in several ways. First, instead of macroeconomic secondary data (i.e Arunatilake et al., 2001; Abadie and Gardeazabal, 2003; Bank et al., 2004; Scheve and Stasavage, 2012; Mokhlis, 2015), or national health survey (i.e Tanielian and Jaycox, 2008; Cesur et al., 2012), the relationship was investigated through a survey that adapted psychometric test with 386 respondents in conflict areas (Lahad Datu and Samporna). Second, unlike prior research that investigated partial of the framework (i.e cost of war on mental health, cost of war on economy, or mental health and economy), this research investigates the holistic and comprehensive perspective by capturing the impact of dispute on mental health, optimism, and consumption behaviour. Third, this research is not an ex-ante or ex-post, but was conducted during the peak of dispute which was on March 2013. The purpose is for the robustness of the result that can mimic the real condition.

War, conflict, or dispute has contributed to the mental health or other psychological issue, especially for those who stayed in conflicted area. Kelman (1997) argued that discussing the impact of war or conflict without gauging its effect psychologically is therefore incomplete. He further discussed how dispute might damage the social psychology of community internationally. Gallagher (2004) studied about the situation of young people condition after the Northern Ireland conflict. He surmised that young people in Northern Ireland still had psychological issue (i.e hatred, discrimination, etc) one to others, and argued that it would take a long period or other public policy to overcome this matter. Meanwhile, Ramanathapillai (2006) addressed psychological trauma as the results of dispute. By investigating the dispute in Sri Lanka, he gathered data of stories of rape, displacement, and killing during the riots against Tamil minority, and concluded that longer time for trauma healing and no jobs available as the cost of the dispute. Other scholars have addressed the importance of psychology counselling as the first priority for government after war or conflict in regards of tackling future social issue (i.e. Yerkes, 1918; Cartwright, 1948; Seligman and Fowler, 2011; Brandon, 2011).

Much research has linked emotion to economy activity. For instance, consumer behaviour area has extensively investigated the association between emotion and consumption (see Cohen and Areni (2001) for the seminal review). Other research papers, such as Isen et al. (1978), found that people tend to do shopping when they feel happy. Kirby et al. (2007) found that people with psychological distress tended to consume alcoholic drinks more than average. Just, Wasink, and Turvey (2009) addressed the fear of aviant influenza had declined the food consumption in campus cafeteria. Furthermore, Azagba and Sharaf (2011) investigated the role stress on consumption, particularly the association between job stress and alcohol and cigarette consumption. They found that job stress has a positive and statistically significant impact on smoking intensity, but only for light smokers, while it has a positive and significant impact on alcohol consumption mainly for heavy drinkers. Additionally, Kageyama (2011) studied the intertemporal consumption and time preference in the framework of biological and economics. His study demonstrated that the biological 
foundation of preferences and motivation in consumption with the view of intertemporal decision making. However, rarely found a research collaborates consumption and psychological cost of war.

Instead of only examining the impact of incursion in Sabah on mental health and consumption, this research examines further by introducing optimism as the moderating variable. We hypothesize that mental health such stress level, as the impact of the incursion, has significant effect on consumption level of Sabahan. This means Sabahan people have more consumption to overcome the stress level due to the dispute.

\section{Data and Measures}

\subsection{Data}

The data used in this study is retrieved from the field survey in Samporna and Lahad Datu on March 2013. Three hundred eighty four questionnaires were used to explore the stress level, optimism value, and consumption level of the citizen in those two cities. The unit of analysis in this study is local people who live in Samporna and Lahad Datu, and never leave the city at least for 6 months meaning that they have been in Samporna and Lahad Datu from October 2012 to March 2013. The respondent was chosen randomly based on the observation of researcher. Total questionnaires collected from both cities were 420, but only 386 could be used.

\subsection{Baseline Model}

The baseline model of this study is the estimation of extra consumption level and extra leisure spending. Extra consumption level is measured by using the ratio of consumption during the dispute divided by average monthly consumption. Meanwhile, extra leisure spending is measured by using ratio of leisure spending during the dispute divided by average spending for leisure (e.g. going to cinema, hanging out, going to karaoke, etc). Based on literature, this consumption model is driven by four variables, which are age level, marital status, income level, and house ownership (see Coombs, 1991; Furnham and Argyle, 1998; Gunter and Furnham, 1998; Otners and McGrath, 2001; Canova et al., 2005; J Love, 2010; Disney and Gathergood, 2010; Jackson, Stoel, and Bradley, 2011). The function is described as follow.

\section{$\{$ extra consumption $\} \vee\{$ Extra Leisure Spending $\}=$ $f$ (age, marital, house ownership, income level)}

To estimate the above model empirically, we run it cross sectionally and estimate the following regression model:

$$
\Delta C O N S=\alpha_{1}+\beta_{1} A G E_{i}+\beta_{2} \text { MARRIED }_{i}+\beta_{3} \text { HOUSE }_{i}+\beta_{41} \operatorname{INCOME}_{i}+\varepsilon_{i}
$$

and

$$
\Delta L E I S=\alpha_{1}+\beta_{1} A G E_{i}+\beta_{2} \text { MARRIED }_{i}+\beta_{3} \text { HOUSE }_{i}+\beta_{41} \operatorname{INCOME}_{i}+\varepsilon_{i}
$$

The symbols $\triangle C O N S$ and $\triangle L E I S$ are the dependent variables, which are extra consumption and extra leisure spending, consecutively. Meanwhile, Age, Married, House, and Income are 
the baseline predictors, which are Age level, marital status, house ownership, and income level, respectively.

\subsection{The Main Model}

According to psychology literature, human psychology during dispute must be taken into account since it might have correlation with decision making (e.g., Thaler and Shefrin, 1981; Tvede, 2002; Chaulk, Johnson, and Bulcroft, 2003; List, 2004). To a certain level, mental health such as stress level could dictate the decision making of consumption just to overcome the fear or sorrow feeling during the dispute. In our study, we examine this phenomenon by introducing stress level as a predictor of extra consumption or extra leisure spending.

To investigate the value of life in influencing the decision making, we consider optimism as another predictor. However, literature documented the moderating role of optimism to overcome hedonic utility and suppress the irrationality of economic decision making (see Brunnermeier and Parker, 2005; Puri and Robinson, 2007). This value could control the extra consumption or extra spending which occurred as the result of stress level during dispute. Therefore, we introduce the interaction model between stress level and optimism to examine whether optimism might deduce the irrationality in consumption and spending due to dispute's stress level. We added these three variables to the baseline model as follow:

$$
\begin{aligned}
& \Delta C O N S=\alpha_{1}+\beta_{1} A_{G E}+\beta_{2} \text { MARRIED }_{i}+\beta_{3} \text { HOUSE }_{i}+\beta_{41} \text { INCOME }_{i}+ \\
& \beta_{5} \text { STRESS }_{i}+\beta_{6} \text { OPTIMISM }_{i}+\beta_{1} \text { STRESS }^{*} \text { OPTIMISM }_{i}+\varepsilon_{i}
\end{aligned}
$$

and

$$
\begin{aligned}
& \Delta L E I S=\alpha_{1}+\beta_{1} A_{G E}+\beta_{2} \text { MARRIED }_{i}+\beta_{3} \text { HOUSE }_{i}+\beta_{41} \text { INCOME }_{i}+ \\
& \beta_{5} \text { STRESS }_{i}+\beta_{6} \text { OPTIMISM }_{i}+\beta_{1} \text { STRESS }^{*} \text { OPTIMISM }_{i}+\varepsilon_{i}
\end{aligned}
$$

\subsection{Measures}

Unlike prior studies in cost of war, this study conducted a survey, where items were developed based on psychometric test. For the demography information, such as "AGE", "MARITAL STATUS", "GENDER", and "INCOME LEVEL", it is based on our intuitive judgment, and strengthened by prior study in economics psychology. Studies such financial literacy study by Roij, Lusardi, and Alessie (2011), affection consumption study by Guven (2012), and intertemporal choice by Samanez-Larkin et al. (2011) addressed those variables as an important factor in cognitive decision making. However, "HOUSE OWNERSHIP" was added because of our observation. In Sabahan culture, the nuclear family has still stayed in one house with different level of consumption. For instance, a married-son stays in his parents' house with his wife, but they have different expenditure, where the house bills (electricity and water usage) are still paid by the parents. Hence, we consider house ownership as another control variable. Stress level was adopted from Depression, Anxiety, Stress Scale of Lovibond and Lovibond (1995). This measure covers over-aroused, tense, unable to relax, touchy, easily upset, irritable, easily startled, nervy, jumpy, fidgety, and intolerant of interruption. This psychometric scale can be used for non-clinical samples and adopted for survey study (see Groth-Marnat, 2003). The optimism was adopted from Life Orientation Test which was developed by Scheiever and Carver (1985). There was 10 items measuring 
individual optimism in life, and consisting of questions such as "In certain time, I usually expect the best", "I am always optimistic about my life", "I don't get upset easily", "I rarely count on good things happen to me", "Overall, I expect more good things to happen to me", etc. This psychometric test was used as survey study, such as in Folkman and Moskowitz (2000), Brissette, Scheier, and Carver (2002), and Thoits (2013). There are two measures of consumption level that used in this research. The first measure is a direct measure of excess consumption, which was calculated from difference between current month consumption and average normal life consumption. Second measure is the extra consumption for leisure, which was calculated from the difference between current month leisure cost and average normal life leisure cost.

\subsection{Goodness of Measures}

The items reliability was tested though Cronbach alpha. Reliability test is the accuracy or precision of a measuring instrument that is the extent to which the respondent can answer the same or approximately the same questions the same way each time. Even though Sekaran (2003) suggested that alpha value of 0.5 would be considered okay, this research used higher threshold, which is Nunnaly and Bernstein (1994). They suggest that Cronbach Alpha value of 0.6 and above is considered to be reliable. It indicates items are homogeneous and measuring the same constructs. For instance, optimism items have CA value of 0.858 indicating inter-consistency was achieved.

This research tests further the validity of questionnaire. Validity test is a test of how well an instrument that is developed measures the particular concept it is intended to measure (Sekaran and Bougie, 2010). The threshold value for items to be remarked as valid is 0.7 each items or 0.7 in average (Hair et al., 2010). Our validity test showed the value of higher than 0.7 in each items, implying the instruments are valid to measure optimism. Hence, we proceeded to the descriptive statistice and inferential statistic.

\section{Estimation}

\subsection{Descriptive Results}

\subsubsection{Stress level}

According to Lovibond and Lovibond (1995), Depression Anxiety Stress Scale is divided into 5 levels, which are: Normal, Mild, Moderate, Severe, and Extremely Severe. Table 1 shows the full detail about stress level, where most of respondents experience severe stage of stress level. $50 \%$ of samples experienced symptom of severe stress level, and $16 \%$ had symptom of extremely severe stress level. This is in line with the condition during data collection, which was taken during the dispute (March 2013). This is also consistent with Benson et al. (2010) and Berntsen et al. (2012) who addressed the occurrence high level of stress as the results of traumatic condition on war or conflict or incursion area. This dossier implies most of Sabahan had experience sleep disturbances, losing appetite, and sexual disturbance during the dispute as they had the symptom of high stress level. Yet, there is small portion of respondents that experienced only normal stage and mild stage of stress level. 
Table 1. Mental Health Description Results

\begin{tabular}{lccc}
\hline & Score Range & Number of Respondents & \% Respondents \\
\hline Normal & $0-14$ & 16 & $4.15 \%$ \\
\hline Mild & $15-18$ & 13 & $3.37 \%$ \\
\hline Moderate & $19-25$ & 101 & $26.16 \%$ \\
\hline Severe & $26-33$ & 193 & $50 \%$ \\
\hline Extremely Severe & $>34$ & 63 & $16.32 \%$ \\
\hline Total & & 386 & $100 \%$ \\
\hline
\end{tabular}

\subsubsection{Statistical descriptive}

Table 2 describes the summary of 386 respondents from the two cities. The mean values and standard deviation are calculated for each variable to facilitate the distribution of the data. Stress level has values range from 13 to 53 . The mean is 25 with standard deviation of 2.193. This information implies the respondents had symptom of severe stress level. The optimism is in 4 likert-scale, where the respondents had minimum value of 2, maximum value of 3.5, and standard deviation of 0.342 . Most of respondents had good value of optimism life orientation which could be seen from mean value f 2.74 .

The dependent variables are two set: extra consumption and extra leisure spending. Note that if the value is lower than 0 , it means the consumption/leisure spending during dispute is lower than average (normal) consumption/leisure spending. The descriptive documents the minimum value was 0.314 and 0.602 for extra consumption and extra leisure spending, respectively. Yet, the mean values are 1.63 and 1.54 for extra consumption/leisure spending, respectively. This means most of Sabahan people had averagely higher consumption/leisure spending during dispute than before dispute.

Table 2. Data distribution of Main Variables

\begin{tabular}{lcccc}
\hline & Min & Max & Mean & Std. Dev \\
\hline Stress Level & 13 & 53 & 25 & 2.193 \\
\hline Optimism & 2 & 3.5 & 2.74 & 0.342 \\
\hline Extra Consumption & 0.314 & 3.438 & 1.63 & 1.761 \\
\hline Extra leisure Spending & 0.602 & 3.611 & 1.54 & 0.5382 \\
\hline
\end{tabular}

\subsubsection{Demographical descriptive}

Table 3 depicts the demographical descriptive of respondents of the predictors from baseline model. The age level was relatively concentrated at the class of productive workers, which is $24-27$ years old ( $29 \%$ of respondents), and $28-32$ years old ( $26 \%$ of respondents). The early stage of productive workers, the 20-23 years old category, was relatively big with $17 \%$ of respondents. Interestingly, there were around $13 \%$ of respondents coming from age category f 15-19 years old. These respondents were also productive workers, where most of them worked in hotel industry, restaurant, and groceries. Moreover, our study consists of $56.74 \%$ male respondents and $43.26 \%$ female respondents. In terms of marital status, our demography results documented $59 \%$ of respondents were single or divorced, and $41 \%$ of respondents was married. This is in line with the demography of Malaysia according to the 2012 national census. 
Table 3. Results of Demographical Descriptive

\begin{tabular}{|c|c|c|c|}
\hline & Category & Number of respondents & $\%$ of Respondents \\
\hline \multirow{5}{*}{ ge Level } & $15-19$ & 49 & $12.69 \%$ \\
\hline & $20-23$ & 67 & $17.36 \%$ \\
\hline & $24-27$ & 112 & $29.02 \%$ \\
\hline & $28-32$ & 99 & $25.65 \%$ \\
\hline & $>32$ & 59 & $15.28 \%$ \\
\hline \multirow{2}{*}{ Gender } & Male & 219 & $56.74 \%$ \\
\hline & Female & 167 & $43.26 \%$ \\
\hline \multirow{2}{*}{$\begin{array}{l}\text { Marital } \\
\text { Status }\end{array}$} & Single/Others & 228 & $59.07 \%$ \\
\hline & Married & 158 & $40.93 \%$ \\
\hline \multirow{3}{*}{$\begin{array}{c}\text { House } \\
\text { Ownership }\end{array}$} & Owned & 241 & $62.44 \%$ \\
\hline & Rent & 132 & $34.20 \%$ \\
\hline & With Parents/Relative & 13 & $3.36 \%$ \\
\hline \multirow{5}{*}{$\begin{array}{l}\text { Income } \\
\text { Level }\end{array}$} & Rm500-900 & 86 & $22.28 \%$ \\
\hline & Rm901-1000 & 63 & $16.32 \%$ \\
\hline & Rm1001-1600 & 89 & $23.06 \%$ \\
\hline & Rm1601-2200 & 86 & $22.28 \%$ \\
\hline & $>\operatorname{Rm} 2200$ & 62 & $16.06 \%$ \\
\hline
\end{tabular}

Further, the house ownership and income level are important predictors of consumption. The consumption of a person that owned a house and rent a house might be different. The demography of the respondents showed that $64 \%$ of them owned the house, meanwhile, $34 \%$ rent the house. Interestingly, there was around 3\% of respondents has still lived with their parents or relative. The income level demography showed that most of respondents had Rm1001-1600 income level (23\%). The lowest income was Rm 500, which was a waiter in restaurant. This low level of income category (Rm500-900) was $22 \%$ of respondents. It is noteworthy that, based on Malaysian Department of Statistic, income per capita in Sabah was Rm1400/month, which is in line with our respondents.

\subsection{Samporna versus Lahad Datu}

Paired T-test is conducted to examine whether there was a significant difference between Samporna and Lahad Datu samples. The objective is to avoid result bias by taking both cities as one sample due to different demography and custom. Table 4 shows there is no significant difference between Samporna sample and Lahad Datu. The optimism, stress level, and consumption level of Samporna and Lahad Datu are similar. This indicates that Samporna and Lahad Datu can be treated as one sample, and by doing so, there would be no bias result.

Table 4. Paired T-Test Results

\begin{tabular}{lccc}
\hline & Mean difference & t Value & Probability \\
\hline Stress Level & 0.28 & 2.184 & 0.029 \\
\hline Optimism & 0.39 & 2.697 & 0.012 \\
\hline Consumption & 0.32 & 4.773 & 0.000 \\
\hline Leisure Cost & 0.27 & 4.793 & 0.000 \\
\hline
\end{tabular}




\subsection{Estimation of Stress, Optimism Life, and Consumption}

This section addresses the estimations of model 3. With a cross-sectional data, we report the probability values based on interactive ordinary least square, as well as coefficient values of predictors. We start from Model 3(a) with only stress level as main predictor in baseline model. All four control variables basically contribute positively to extra consumption, but only age level and income level were statistically significant. The R2 of the model is about $10.6 \%$. We then re-run the baseline model with only optimism as main predictor (Model 3b). The results are also in line with Model 3(a), where only age level and income level had statistically significant with extra consumption during dispute. Interestingly, the optimism of life orientation contributed a negative sign, and significant at 5\% level. This indicates if Sabahan people had more optimism value, they tended not to be influenced by the dispute, and there was no extra consumption (normal life). The R2 of the model is good enough, which is about $17.6 \%$.

We continue to the estimation of Model $3 \mathrm{c}$, and find similar conclusion. Table 5 documents that age level, income level, stress level, optimism, and the interaction variable had statistically significant on extra consumption. We find also that optimism and the interaction contribute negatively to the model. This relationship means that stress level is the determinant to extra consumption during dispute. The higher the stress level because of the dispute, the higher is the consumption of Sabahan. However, the value of life orientation, which is optimism, might control the stress level and reduce the consumption. If the Sabahan people experience stress due to the dispute of Sulu's Sultanate, those people with high value of optimism in life might maintain their consumption, and would not be influenced by the dispute.

\subsection{Estimation of Stress, Optimism Life, and Leisure Expenditure}

Model 4(a) finds that the results are still consistent with the estimates in Model 3. Both model shows that age level and income level are the predictors, and it is positively and significantly affects the consumption. Stress level is significant at $5 \%$ level implying the higher stress level of Sabahan people during the dispute, the higher leisure spending. The R2 is robust enough with a value of $27.1 \%$. Further, Model 4(b) has the same remark where optimism contributed negatively to extra leisure spending, and statistically significant at $5 \%$ level. Similar with the explanation of Model 3(b), this means Sabahan people with high optimism value in their value would not be influenced by the dispute, and thereby, would not spend more for leisure.

We proceed to the results of Model 4(c), where the baseline model adds with stress level, optimism, and the interaction variable. First, the model is good with R2 value of $28.2 \%$. The predictors in baseline model contributed positively, yet, only age level and income level has significant effect on extra leisure spending. Note that age level in this model was significant at $10 \%$ level, and income level was significant at $1 \%$ level. Stress level contributed positively to the model, and was significant at $1 \%$ level implying the higher stress level during dispute, might result higher leisure spending. Conversely, the optimism is significantly associated with extra leisure spending, but in inverse relationship. The interaction variable remarks the same, where it was significant at 5\% level, but it contributed negatively. These results indicate that even though Sabahan people had experience high stress level, the spending in leisure can be maintained as long as they had value of optimism. 


\section{Analysis}

Our study reveals that two baseline variables do significantly affect the extra consumption during the dispute, namely, age level and income level. Yet, house ownership, gender, marital status does not significantly influence the entire extra consumption estimation model. Even after introducing another proxy of consumption, extra leisure spending, we still find that only age level and income level had the effects on the estimation model (Model 4). These results demonstrate that level of age and income have played important role in the consumption decision during the dispute. This is in line with Furnham and Thomas (1984).

Our results shows age had positive beta coefficient, indicating the older a Sabahan, the more consumption/spending executed. This is consistent with previous studies such as Furnham and Argyle (1998), Gunter and Furnham (1998), Canova, Rattazi, and Webley (2005).

Interestingly, even though previous research in the association between consumption and gender (i.e., Otners and McGrath, 2001; Jackson, Stoel, and Bradley, 2011), marital status (i.e., Coombs, 1991; Love, 2010), and house ownership (i.e., Disney and Gathergood, 2010; Chamon and Prasad, 2010) documented significant effects on consumption, our findings concluded it differently. The emotional stability due to the dispute might also explain why gender, marital status, and house ownership could not be the predictor for consumption/leisure spending (e.g., Brandstatter, 1996; Brandstatter and Guth, 1998; Nyhus and Webley, 2001).

We further find that stress level presented significant positive value suggesting that the more Sabahan experienced stress, the more was consumption or spending. According to Furnham and Argyle (1998), Brandstatter (1996), Brandstatter and Guth (2000), Nyhus and Webley (2001), and Canova, Rattazi, and Weblye (2005), emotional stability plays important role in consumption or spending behaviour. The dispute in Sabah Malaysia gave stress to the local, and as the outcome, Sabahan did more consumption and leisure spending to overcome their stress feeling. Moreover, Hirschman and Holbrook (1982), and Gardner (1985) addressed hedonic consumption as those facets of consumer behaviour that relate to the multisensory, fantasy and emotive aspects. Their emotion involves in the consumption decision making as a way to relieve or suppress the worrisome or anxiety. Therefore, occurred stress level because of dispute has encouraged people to do more consumption or leisure spending.

In terms of optimism, we find negatively and significantly contribution on consumption during dispute in Sabah. This means the higher value of optimism, the lower the extra consumption during dispute. Sabahan with high value of optimism might see the dispute as temptation from God or temporary problem that can be resolved by government. This is consistent with theoretical prediction of Brunnermeier and Parker (2005), who argued optimists have lower value of risk taker in their utility function, and make them to maintain their intertemporal savings. McKay and Dennet (2009) addressed optimistic person as an adaptive person who underestimates the current risk and expects a better reality in the future. This is tally with the condition in Sabah, where the incursion might be viewed as low value of risk because their value in believing better future is very strong.

This research interacts stress level with optimism to answer how mental health, value of optimism, and consumption are related one to another. Our estimation model showed the interaction was negatively significant to extra consumption during dispute in Sabah. Even though stress level might induce the consumption/leisure spending, optimism value might reduce that stress effect, and encourage people in dispute area to have more savings. This is consistent with self-control model in economics psychology (see Smith, 1759; Freud, 1986; Tvede, 2002). 
Using the postulate of Thaler and Shefrin (1981), we can describe self-control as a battle between a Doer self, who enjoys utility in the present, and a Planner self, responsible for making decisions that provide utility for all future Doer selves. Our findings suggest that optimism plays an important role in the balance of power between the Planner self and the Doer self during dispute. The optimists tend to control their feeling, be a planner self, setting aside more resource for future enjoyment of future problems. This explains how stress can be overcome by optimist, and keeps their financial decision to be a saver.

\section{Conclusion}

Our study addresses the recent phenomenon of psychological cost of dispute in Sabah Malaysia, and is motivated by the curiosity on whether dispute in Sabah between Malaysia and Sultanate of Sulu encouraged increasing stress level for Sabahan, and whether the increasing stress level motivated Sabahan to have extra consumption and leisure spending to suppress the worrisome or fear feeling, or in economics term whether dispute in Sabah stimulated hedonic utility in consumption behaviour. To make it more robust, this paper extends the study by gauging cognitive psychology, where value of optimism was introduced as moderator between stress level and extra consumption/spending. In short, the objective of this research is to examine whether dispute in Sabah cost psychologically and economically.

The findings show dispute brought psychological problem for local. The study shows the higher the stress level, people tended to have more consumption or leisure spending. Interestingly, when stress level interacted with value of optimism life orientation, they tended to save their money for future by reducing their consumption or leisure spending. This implies Sabahans with good optimism in their life tended to believe there is a rainbow after heavy rain, and they kept their money and not doing extra consumption to suppress their fear or worrisome feeling.

Different from prior research such as Arunatilake et al. (2001), Abadie and Gardeazabal (2003), and Cesur et al. (2012), this research developed the model under economic psychology literature (i.e., Cohen and Areni, 2001; Kahneman and Tversky, 1979; Isen et al., 1978) by taking individual as unit analysis and examining their cost of psychology during war. Our results bring implication about certain conceptualized frameworks, and empirical evidence that dispute might have economy impact such as bank-rush, reactive inflation, and capital flight through aggregate individual biased economy decision making. In more detail, our findings enrich the literature of economics psychology where we address stress level and optimism as factors that might influence the consumption level.

In addition, this study might have important contribution to policy maker. Understanding the link between stress level, optimism, and consumption can help designing precautionary behaviour such as design tax, personal finance, and retirement policies. Reciprocal with the review of Cramer (2002), the uncontrol condition such as conflict, war, or dispute also tells policy maker that war only give psychological problem leading to extra consumption. For instance, the Sultanate Sulu dispute against Malaysia might result a decreasing wealth and increasing mental health to Sabah Malaysia, which is a trigger for worse outcome such as coup, political instability, and sporadic separation movement (i.e., DeFronzo, 1991; Alesina and Perroti, 1996; Miller, 2011; Dupas and Robinson, 2012). This means that policy maker has to know the fastest solution to overcome dispute, hence, it will avoid depleting wealth of nation.

Further, government can also help regulating the timing of macroeconomics announcement (i.e. announcement of unemployment, inflation, petrol hikes, and tax levels). Giving educational ads to enhance optimism of people can lead to reduction of extra consumption. Moreover, enhancing optimism might lead in increasing wealth of a country in 
a long term because of less consumption. In the context of the dispute, enhancing optimism value might reduce the worrisome and fear factors. Yet, we aware the limitation of our study that we assume the stress level was due to the dispute instead of other socio-economy issues. The only resort to justify our assumption is that the descriptive statistic that showed most of samples has severe stress level.

This paper exploits the information during the Sabah-Sulu dispute in survey data to study the impact of stress level on consumption behaviour, and the moderating effect of optimism on that relationship. So far, survey data has not been used extensively in this field. In addition, investigating psychology cost of dispute is not routinely tested in economics psychology field due to the limitation of scope or sample of research. Even though so, all our findings need to be validated by further research on other perspectives of psychological measurement (other mental health measurements), other measurements of intertemporal consumption, and other dimensions of value of life as moderating effect (i.e., personality trait, religiousity intensity, lifestyle value, etc) in regards to test the psychological cost of war/conflict. Another suggestion for future research is to examine whether or not the impact of macroeconomics news or announcement on consumption patterns depend on stress level, and moderated by optimism. This will be an interesting journey for future research.

\section{References}

Alesina, A. \& Perotti, R. (1996), Income distribution, political instability, and investment, European Economic Review, 40(6), pp. 1203-1228.

Arunatilake, N., Jayasuriya, S. \& Kelegama, S. (2001), The economic cost of the war in Sri Lanka, World Development, 29(9), pp. 1483-1500.

Azagba, S. \& Sharaf, M. F. (2011), The effect of job stress on smoking and alcohol consumption, Health economics review, 1(1), pp. 1-14.

Bank, S. A., Stark, K. J. \& Thorndike, J. J. (2008), War and taxes, The Urban Insitute.

Benson, M. A., Compas, B. E., Layne, C. M., Vandergrift, N., Pašalić, H., Katalinksi, R. \& Pynoos, R. S. (2011), Measurement of post-war coping and stress responses: A study of Bosnian adolescents, Journal of Applied Developmental Psychology, 32(6), pp. 323-335.

Berntsen, D., Johannessen, K. B., Thomsen, Y. D., Bertelsen, M., Hoyle, R. H. \& Rubin, D. C. (2012), Peace and War Trajectories of Posttraumatic Stress Disorder Symptoms Before, During, and After Military Deployment in Afghanistan, Psychological science, 23(12), pp. 1557-1565.

Brandon, S. E. (2011), Impacts of psychological science on national security agencies post9/11, American Psychologist, 66(6), p. 495.

Brandstätter, H. (1996), Saving, income, and emotional climate of households related to personality structure, VSB-CentER Savings Project, Progress Report, 38.

Brandstätter, H. \& Güth, W. (2000), A psychological approach to individual differences in intertemporal consumption patterns, Journal of Economic Psychology, 21(5), pp. 465-479.

Brissette, I., Scheier, M. F. \& Carver, C. S. (2002), The role of optimism in social network development, coping, and psychological adjustment during a life transition, Journal of personality and social psychology, 82(1), pp. 102-111.

Brunnermeier, M. \& Parker, J. (2005), Optimal expectations, American Economic Review, 95, pp. 1092-1118.

Canova, L., Rattazzi, A. M. M. \& Webley, P. (2005), The hierarchical structure of saving motives, Journal of Economic Psychology, 26(1), pp. 21-34.

Cartwright, D. (1948), Social psychology in the United States during the second world war, Human Relations, 1(3), pp. 333-352. 
Cesur, R., Sabia, J. J. \& Tekin, E. (2011), The psychological costs of war: Military combat and mental health (No. w16927), National Bureau of Economic Research.

Chaulk, B., Johnson, P. J. \& Bulcroft, R. (2003), Effects of marriage and children on financial risk tolerance: A synthesis of family development and prospect theory, Journal of Family and Economic Issues, 24(3), pp. 257-279.

Cohen, J. B. \& Areni, C. S. (1991), Affect and consumer behaviour, In: T. S. Robertson \& H. H. Kassarjian (Eds.), Handbook of consumer behaviour (pp. 188-240), Englewood Cliffs, NJ: Prentice Hall.

Coombs, R. H. (1991), Marital status and personal well-being: A literature review, Family relations, pp. 97-102.

Cramer, C. (2002), Homo Economicus Goes to War: Methodological Individualism, Rational Choice and the Political Economy of War, World Development, 30(11), pp. 1845-1864.

DeFronzo, J. (1991), Revolutions and revolutionary movements, Westview Press.

Disney, R., Gathergood, J. \& Henley, A. (2010), House Price Shocks, Negative Equity, And Household Consumption In The United Kingdom, Journal of the European Economic Association, 8(6), pp. 1179-1207.

Dupas, P. \& Robinson, J. (2012), The (hidden) costs of political instability: Evidence from Kenya's 2007 election crisis, Journal of Development Economics, 99(2), pp. 314-329.

Folkman, S. \& Moskowitz, J. T. (2000), Positive affect and the other side of coping, American psychologist, 55(6), pp. 647-654.

Freud, S. (1986), The Essentials of Psycho-Analysis: The Definitive Collection of Sigmund Freud's Writing, Penguin books.

Furnham, A. \& Argyle, M. (1998), The psychology of money, Psychology Press.

Gallagher, T. (2004), After the war comes peace? An examination of the impact of the Northern Ireland conflict on young people, Journal of Social Issues, 60(3), pp. 629-642.

Gardner, M. P. (1985), Mood states and consumer behavior: a critical review, Journal of Consumer Research, pp. 281-300.

Goldsmith, A. (2008), The governance of terror: Precautionary logic and counterterrorist law reform after September 11, Law \& Policy, 30(2), pp. 141-167.

Groth-Marnat, G. (2003), Handbook of psychological assessment.

Guven, C. (2012), Reversing the question: Does happiness affect consumption and savings behavior? Journal of Economic Psychology, 33(4), pp. 701-717.

Hair, J. F., Black, W. C., Babin, B. J. \& Anderson, R. E. (2010), Multivariate data analysis, Prentice-Hall, Upper Saddle Rive.

Hirsch, B. T. \& Mehay, S. L. (2003), Evaluating the labor market performance of veterans using a matched comparison group design, Journal of Human Resources, 38(3), pp. 673-700.

Hirschman, E. C. \& Holbrook, M. B. (1982), Hedonic consumption: emerging concepts, methods and propositions, The Journal of Marketing, pp. 92-101.

Isen, A. M., Shalker, T. E., Clark, M. \& Karp, L. (1978), Affect, accessibility of material in memory, and behavior: A cognitive loop? Journal of personality and social psychology, $36(1)$, p. 1.

Jackson, V., Stoel, L. \& Brantley, A. (2011), Mall attributes and shopping value: Differences by gender and generational cohort, Journal of Retailing and Consumer Services, 18(1), pp. 1-9.

Just, D. R., Wansink, B. \& Turvey, C. G. (2009), Biosecurity, Terrorism, and Food Consumption Behavior: Using Experimental Psychology to Analyze Choices Involving Fear, Journal of Agricultural and Resource Economics, pp. 91-108.

Kageyama, J. (2011), The intertemporal allocation of consumption, time preference, and lifehistory strategies, Journal of Bioeconomics, 13(2), pp. 79-95. 
Kelman, H. C. (1997), Social-psychological dimensions of international conflict, Peacemaking in international conflict: Methods and techniques, pp. 191-237.

Kirby, B., Richards, H. L., Mason, D. L., Fortune, D. G., Main, C. J. \& Griffiths, C. E. M. (2008), Alcohol consumption and psychological distress in patients with psoriasis, British Journal of dermatology, 158(1), pp. 138-140.

List, J. A. (2004), Neoclassical theory versus prospect theory: Evidence from the marketplace, Econometrica, 72(2), pp. 615-625.

Love, D. A. (2010), The effects of marital status and children on savings and portfolio choice, Review of Financial Studies, 23(1), pp. 385-432.

Lovibond, P. F. \& Lovibond, S. H. (1995), The structure of negative emotional states: Comparison of the Depression Anxiety Stress Scales (DASS) with the Beck Depression and Anxiety Inventories, Behaviour research and therapy, 33(3), pp. 335-343.

McKay, R. T. \& Dennett, D. C. (2009), The evolution of misbelief, Behavioral and Brain Sciences, 32(6), p. 493.

Miller, A. C. (2011), Debunking the Myth of the "Good" Coup d'État in Africa, African Studies Quarterly, 12(2).

Mokhlis, S. (2015), Influences on Malaysian business students' retailling career preferences, Actual Problems of Economics, Issue 5 (167), pp. 378-385.

Nyhus, E. K. \& Webley, P. (2001), The role of personality in household saving and borrowing behaviour, European journal of personality, 15(S1), S85-S103.

Otnes, C. \& McGrath, M. A. (2001), Perceptions and realities of male shopping behaviour, Journal of Retailing, 77(1), pp. 111-137.

Puri, M. \& Robinson, D. T. (2007), Optimism and economic choice, Journal of Financial Economics, 86(1), pp. 71-99.

Ramanathapillai, R. (2006), The politicizing of trauma: A case study of Sri Lanka, Peace and Conflict, 12(1), pp. 1-18.

Ross, M. L. (2004), What do we know about natural resources and civil war? Journal of Peace Research, 41(3), pp. 337-356.

Samanez-Larkin, G. R., Mata, R., Radu, P. T., Ballard, I. C., Carstensen, L. L. \& McClure, S. M. (2011), Age differences in striatal delay sensitivity during intertemporal choice in healthy adults, Frontiers in neuroscience, 5.

Scheier, M. F. and Carver, C. S. (1985), Optimis, coping, and health: Assessment and implication of generalized outcome expectancies, Health Psychology, 4, pp. 219-247.

Scheve, K. \& Stasavage, D. (2012), Democracy, War, and Wealth: Lessons from Two Centuries of Inheritance Taxation, American Political Science Review, 106(1), pp. 82-102.

Sekaran, U. (2003), Research Methods for Business: A skill building approach, John Wiley and Sons Inc., New York.

Sekaran, U. \& Bougie, R. (2010), Research methods for business: a skill building approach, Wiley, UK.

Seligman, M. E. \& Fowler, R. D. (2011), Comprehensive Soldier Fitness and the future of psychology, American Psychologist, 66(1), 82.

Smith, A. (1759), The theory of moral sentiments, London: A. Millar.

Tanielian, T. L. \& Jaycox, L. H. (Eds.) (2008), Invisible wounds of war: Psychological and cognitive injuries, their consequences, and services to assist recovery (Vol. 720), Rand Corporation.

Thaler, R. H. \& Shefrin, H. M. (1981), An economic theory of self-control, The Journal of Political Economy, pp. 392-406.

Thoits, P. A. (2013), Self, identity, stress, and mental health. In: Handbook of the sociology of mental health (pp. 357-377), Springer Netherlands. 
Thoits, P. A. (2013), Self, identity, stress, and mental health. In: Handbook of the sociology of mental health (pp. 357-377), Springer Netherlands.

Tvede, L. (2002), The psychology of finance: understanding the behavioural dynamics of markets (Vol. 243), Wiley. com.

Tversky, A. \& Kahneman, D. (1992), Advances in prospect theory: Cumulative representation of uncertainty, Journal of Risk and uncertainty, 5(4), pp. 297-323.

Van Rooij, M., Lusardi, A., \& Alessie, R. (2011), Financial literacy and stock market participation, Journal of Financial Economics, 101(2), pp. 449-472.

Yerkes, R. M. (1918), Psychology in relation to the war, Psychological Review, 25(2), p. 85. 